\title{
FORENSIC EXPERTISE OF SIGNATURES AND HANDWRITING - MULTIDISCIPLINARY APPROACH
}

\author{
UDC 343.982
}

\section{Filip Mirić1, Dragana Rodić Aranđelović}

${ }^{1}$ Associate at Postgraduate Study Services, Faculty of Law, University of Niš, Serbia

${ }^{2}$ Students and Researchers' Career Development Center, University of Niš, Serbia

\begin{abstract}
Forensic expertise of signatures and handwriting is a very important activity in criminalistics. It reveals whether the defendant is the author of the disputed text or has signed the disputed document. This type of expertise is most often used in cases when it is necessary to prove the existence of the criminal offense of forging a document, but also in many other cases (such as expertise of suicide letters or contracts), which indicates the need for a multidisciplinary approach to exploring of this kind of expertise.

This paper presents the basic characteristics of this form of expertise and indicates the difficulties that may arise in practice. The aim of this paper is to identify opportunities for further development of signature and handwriting expertise in theory and practice, as a powerful tool for detecting many crimes and their perpetrators.
\end{abstract}

Key words: forensic expertise, signature and handwriting, criminalistics

\section{INTRODUCTION}

In court proceedings, forensic expertise is instituted when certain expert knowledge possessed by an expert in a given field of expertise is required to establish legally relevant facts. Thus, in accordance with the well-known legal principle Iura novit curia (The judges knows the law), the expert's finding and opinion never contain statements on legal issues. In court proceedings (especially in criminal cases), there is often a need for obtaining various types of expertise to establish legally relevant facts falling within the scope other sciences and disciplines, whose establishment requires specific knowledge that the court does not possess. Forensic expertise includes discovering facts which are important for clarifying and resolving criminal matters by using special professional knowledge or special technical

Received October $28^{\text {th }} 2020 /$ Accepted December $12^{\text {th }} 2020$

Corresponding author: Filip Mirić, LL.D., Research Associate, Associate at Postgraduate Study Services, Faculty of Law, University of Niš, Trg Kralja Aleksandra 11, 18000 Niš, Serbia. E-mail: filip@prafak.ni.ac.rs Dragana Rodić Aranđelović, BEcn, with Honrs, Students and Researchers' Career Development Center, University of Niš, Serbia. E-mail: dragana_rodich@yahoo.com. 
skills, which constitute an expert finding, and by giving a professional opinion on the discovered facts, which constitutes an expert opinion (Jovašević, 2006: 52).

The expertise of signatures and handwriting is one of the areas where forensic expert knowledge is frequently required and applied. It commonly implies graphoscopic examination of signatures or handwriting but, in some cases, there is a need for a graphological expertise, particularly given the fact that graphology is a science that strives to explain one's character, moral and intellectual characteristics by examining one's handwriting (Vujaklija, 1986: 183). Graphological expertise is especially important when determining endogenous crime factors. Graphology and criminology are two separate sciences but they are closely correlated by the subject matter of research.

Expert examination of signatures and handwriting is a very important criminal activity. It reveals whether the defendant is the author of the disputed text or has signed the disputed document. This type of expertise is most often used in cases when it is necessary to prove the existence of the criminal offense of forging a document, but also in many other cases (such as expertise of suicide letters). To our knowledge, in the criminal investigation literature, forensic expertise of signatures and handwriting by using slide projectors has been analyzed in fragments.

This paper will present the basic characteristics of this form of expertise and the difficulties that may arise in practice. The aim of this paper is to identify opportunities for further development of signature and handwriting expertise in theory and practice.

\section{BASIC CHARACTERISTICS OF SIGNATURE AND HANDWRITING EXPERTISE}

A signature is a "handwritten name and surname at the end of a document, text, picture, etc." (Matica Srpska, 2007: 987) ${ }^{1}$, which serves to verify the person's identify or endorse the information provided in the document. Over time, as the act of signing one's name and surname largly becomes mechanical, most signatures get illegible or reduced to a sum of lines or initials, which ultimately aggravates their forensic expertise. Signature expertise is used whenever it is necessary to determine whether the defendant has signed the disputed document.

A signature can be forged in three ways: by imitating, copying, or distorting one's own handwriting. Imitation is an attempt to include all the elements of the original signature in the forged signature; in such a case, it is most difficult to determine the identify of the forger. In the past, signatures used to be copied by using indigo (carbon copy) paper, nowadays, forgers use modern scanners for the same purpose. A signature may also be forged by distorting one's own handwriting; in such a case, it is possible to determine the identity of the forger because the forger inevitably includes elements of one's own handwriting into the forged signature, rather than the elements of the handwriting that is being forged, which is the case with forging signatures by imitation. Notably ,if the two signatures are absolute identical, the prevailing position of the handwriting and signature experts is that it is most likely a forgery because a person can never sign his/her name and surname in exactly the same way twice. Namely, the method of signing depends not only on individual characteristics but also on the means by which it is signed (pen, pencil), the

\footnotetext{
${ }^{1}$ See: Matica Srpska (2007). Rečnik srpskog jezika (Dictionary of Serbian Language), Novi Sad: Matica srpska
} 
quality and type of paper, and even the mental state of the signatory. The next part of the paper will focus on the forensic expertise of handwriting.

The need for handwriting expertise arises when there is suspicion that a handwritten text has been falsified. Handwriting can be falsified by imitating another's handwriting or by distorting one's own, in order to mislead others about the author of the text.

Extensive material is needed for this kind of expertise. In addition to the document that contains the disputed handwriting, it is necessary to obtain the undisputed (original)handwriting of the person who is suspected to have written the disputed text by hand (Đurđić, 2012: 109-110). This can be done by obtaining two types of evidence.

The first group comprises texts that were indisputably written by the defendant; these may include various private files, notes (etc.), which were collected in the course of police operative work. Such texts are especially important because they can indicate the basic characteristics of the defendant's handwriting.

The second group includes texts created by dictation. The writing means and conditions (pencil, fountain pen, defendant's posture and hand position) should be as similar as possible to the conditions in which the disputed document was created. It is sometimes useful to prepare a dictation text in advance, which will contain characteristic words from the disputed document. Graphological, graphometric and graphic methods are used in handwriting expertise (Đurđić, 2012: 111), all of which may contribute to a more comprehensive expertise of one's handwriting.

Each person's handwriting has some general features, such as: letter shapes, legibility, writing speed, writing angle, initial and final strokes, the use of dashes, periods (full stops, dots), punctuation marks, and diacritical marks. As these general features have individual forms of expression, each person's handwriting thus develops specific characteristics, which are unique and distinctive for each script or, and useful in the process of establishing one's identity.

How is handwriting forensically examined in practice? By comparing the general and the specific characteristics of the handwriting contained in the disputed and the undisputed text, a forensic expert may detect a number of matching or corresponding features. In order to conclude that the disputed and the undisputed text was written by the same person, there must be a certain number of matching features, but the number is not explicitly predetermined; thus, the forensic experts' statements primarily rest on their own experiences (Đurđić, 2012: 112).

The need for a graphoscopic and graphological expertise of a signature may arise in criminal proceedings when determining whether the defendant has signed the disputed document. This may be illustrated by case law. Thus, according to the Decision of the Commercial Court of Appeals, Pž. 3802/2012 (2) of 11 May 2012, the judge established not to have the specialist knowledge needed to determine the identity of the person who signed the disputed document and ordered the signature to the examined by an expert in graphology. The decision stated: "In addition, the appellant does not propose the process of adducing the evidence by appropriate graphological expertise on the circumstance considering who received the summons for the hearing, i.e. who signed the return receipt, because, as stipulated in the appeal, the appellant believes that the court has enough knowledge to assess this issue. Yet, graphological expertise requires special knowledge that the court does not possess. Therefore, the first instance court properly assessed that the authenticity of the signature can only be checked by graphological expertise, and not by a free assessment of the acting court. Furthermore, in this specific case, in his proposal for restitution and the appeal against the decision of 26 January 2012, the appellant submitted 
the signatures of all persons authorized by the appellant to receive letters, as well as his own signature and the signature of his trainee lawyer, without specifying or stating whether there are other persons employed in his law office in addition to the said trainee (Decision of the Commercial of the Court of Appeals, Pž. 3802/2012 (2) dated 11 May 2012). ${ }^{2}$

In criminal proceedings, forensic expertise of signatures and handwriting is used in the process of detecting and proving criminal offences of personal documents forgery and falsification of official documents. In civil law proceedings, it is most commonly used for establishing relevant facts in the law of succession, family and obligations (torts and contracts).

Expertise of signatures and manuscripts is important for economic practice and economic activity. Namely, the falsification of signatures and handwriting when concluding various contracts makes their volatility. At the same time, such contracts are particularly detrimental to economic activity because they slow it down, making it uncertain. Therefore, the expertise of signatures and manuscripts has a multidisciplinary significance and contributes to the preservation of the social and economic system.

\section{PROSPECTS FOR THE DEVELOPMENT OF GRAPHOSCOPIC AND GRAPHOLOGICAL EXPERTISE}

Graphological and graphoscopic expertise is widely used in both criminal and civil court proceedings. These forms of forensic expertises are especially important when determining the authorship of incriminated documents, which may also contain threats. The sociolinguistic profiling of the author has proved to be of great help to the police services in the process of eliminating suspects, and numerous solved cases show that signature and handwriting analysis of the disputed text may provide significant information about the author, with varying degrees of precision.

The linguistic method of identification has been applied in criminal investigations for establishing the authenticity of suicide letters, discovering the authors of various threatening letters, ransom requests in abduction cases, text messages from mobile phones or letters written by stalkers, etc. In civil disputes, it has been used in authenticating the author of a will or a life maintenance contract, etc. Due to the more extensive use of electronic written media (such as emails, blogs or SMS messages), the use of printers instead of typewriters and less frequent use of pens, the need for identification of authorship on the basis of linguistic expertise has increased. In the digital environment, determining the authorship of printed or computer-typed texts by using traditional document analysis techniques (such as graphological handwriting analysis) is no longer possible (Nikolić-Novaković, 2017: 180). The experiences of forensic linguists are also important in detecting threats and blackmail, especially if they have been made in written form. ${ }^{3}$ Moreover, knowledge in the field of forensic linguistics may be highly useful in detecting the criminal offences of terrorism, organized crime, various forms of forgery, etc. Forensic linguistics certainly has its place in trial proceedings, where a forensic linguist may act in the capacity of an expert

\footnotetext{
${ }^{2}$ Rešenje Privrednog apelacionog suda Pž. 3802/2012 (2 )/Decision of the Commercial Court of Appeal, Pž. 3802/2012 (2) of 11 May. 2012, citied after Paragraph Lex, the database of legislative actsand court decisions. ${ }^{3}$ See more: Sveučilište u Zadru: Forenzička lingvistika, hvatanje ucjenjivača analizom pisma (Forensic Linguistics: detecting blackmailers by analysing blackmailer letters, Webpage: University of Zadar), accessed 17 July 2020 https://www.unizd.hr/Portals/32/medijska\%20pracenost/2010_17_velj\%20Unizd_\%20Forenzi\%C4\%8Dka\%201 ingvistika,\%20hvatanje\%20ucjenjiva\%C4\%8Da\%20analizom\%20pisma.pdf
} 
witness, especially in cases where it has to be proven that the disputed document or a video recording has been authored by the defendant (Mirić, 2017: 491).

In order for ensure further development of graphological and graphoscopic expertise in the Republic of Serbia, it is necessary to create conditions for the professional development of qualified staff in this area. In Serbia, the structure of experts in graphoscopy and graphology Serbia is currently unfavorable, which may be illustrated by the fact that the Registry of court experts kept by the Ministry of Justice of the Republic of Serbia comprises a list of only 35 experts in graphoscopy. ${ }^{4}$

Finally, it may be concluded that the forensic expertise of signatures and handwritings is an important means of collecting evidence for the detection of many criminal offences and their perpetrators. Yet, the main obstacle to the development of this type of expertise is certainly the lack of scientific studies which would systematically address the challenges of this type of expertise, as well as the insufficient number of graphoscopy experts in the judicial system of the Republic of Serbia. These problems should be actively addressed in the years to come.

\section{REFERENCES}

Đurđić, V. (2012) Osnovi kriminalistike (Intoduction to Criminalistics), Niš: Centar za publikacije Pravnog fakulteta u Nišu.

Jovašević, D. (2006) Leksikon krivičnog prava (Lexicon of Criminal Law), Beograd: Službeni glasnik.

Mirić, F. (2017) The Application of Forensic Linguistics in Criminalistics, "Archibald Reiss Days", Thematic conference proceedings of international significance, Academy of Criminslistic and Police Studies, vol. 1, pp. 490-495.

Nikolić-Novaković, L. (2017) Forenzička lingvistika-primena metoda forenzičke lingvistike u kriminalističkim istragama pretnje(Forensic linguistics-application of methods of forensic linguistics in criminal investigation of threats), Banjaluka: Evropski defendologija centar.

Matica srpska (2007). Rečnik srpskog jezika (Dictionary of Serbian Language), Novi Sad: Matica srpska.

Vujaklija, M. (1986) Leksikon stranih reči i izraza, fototipsko izdanje (Lexicon of foreign words and phrases, phototype edition), Beograd: Prosveta.

\section{JUDICIAL PRACTICE}

Rešenje Privrednog apelacionog suda, Pž. 3802/2012(2) od 11.5.2012. (Decision of the Commercial Court of Appeal), Paragraph Lex database

\section{INTERNET SOURCES}

Ministarstvo pravde Republike Srbije: Registar sudskih veštaka Ministarstva pravde Republike Srbije (Register of court experts of the Ministry of Justice of the Republic of Serbia), Beograd; https://www.mpravde.gov.rs/ court-experts.php , accessed 18 July2020.

Sveučilište u Zadru:Forenzička lingvistika, hvatanje ucjenjivača analizom pisma(University of Zadar, Croatia: Forensic Linguistics: detecting blackmailers by analysisn blackmaler letters),

http://www.unizd.hr/Portals/32/medijska\%20pracenost/2010_17_velj\%20Unizd_\%20Forenzi\%C4\%8Dka\%20li ngvistika,\%20hvatanje\%20ucjenjiva\%C4\%8Da\%20analizom\%20pisma. pdf , accessed July, 17, 2020.

${ }^{4}$ See: Registar sudskih veštaka Ministarstva pravde Republike Srbije (Register of court experts of the Ministry of Justice of the Republic of Serbia), https://www.mpravde.gov.rs/court-experts.php , accessed July 182020. 


\section{VEŠTAČENJE POTPISA I RUKOPISA - MULTIDISCIPLINARNI PRISTUP}

Veštačenje potpisa i rukopisa je veoma važna kriminalistička aktivnost. Njime se otkriva da li je okrivljeni autor spornog teksta ili je potpisao sporni dokument. Ovaj tip veštaćenja se najčešće koristi u slučajevima kada treba dokazati postojanje krivičnog dela falsifikovanje isprave, ali i u mnogim drugim slučajevima (poput veštačenja oproštajnih pisama ili ugovora), što ukazuje na potrebu multidisciplinarnog pristupa njegovom izučavanju.

U radu će biti prikazane osnovne karakteristike ovog oblika veštačenja, ali i ukazano na teškoće koje se mogu javiti u praksi. Cilj rada je pronalaženje mogućnosti za dalji razvoj veštačenja potpisa i rukopisa u teoriji i praksi, kao moćnog sredstva za otkrivanje mnogih krivičnih dela i njihovih učinilaca.

Ključne reči: veštačenje potpisa i rukopisa, kriminalistika 